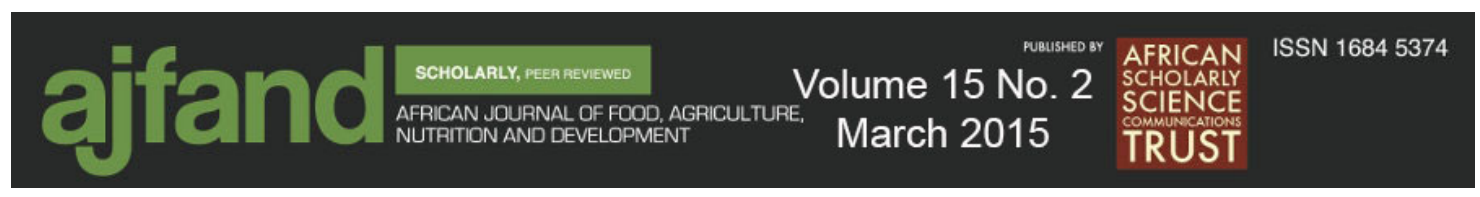

\title{
CHEMICAL QUALITY OF COMMON BEANS AS INFLUENCED BY GENOTYPE AND ALUMINIUM RATES UNDER TWO SOIL LIMING REGIMES
}

\author{
Hirpa $L^{1 *}$, Nigussie-Dechassa R. $^{2}$, Setegn $G^{3}$ and G Bultosa ${ }^{4}$
}

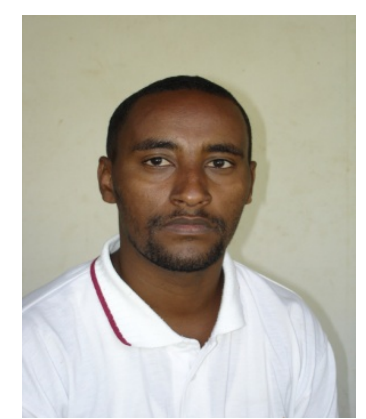

HirpaLegesse

*Corresponding author email: hirpa.leg@gmail.comOR ohirpa@yahoo.com

${ }^{1}$ Wollega University, Department of Plant Science P.O. Box 395, Nekemte, Ethiopia

2,Haramaya University, Department of Plant Sciences, P.O. Box 138, Dire Dawa, Ethiopia

${ }^{3}$ International Institute of Tropical Agriculture, 32 Poplar Road, Avondale, Lusaka, Zambia

${ }^{4}$ Department of Food Science and Technology, Botswana College of Agriculture, Gaborone, Botswana 


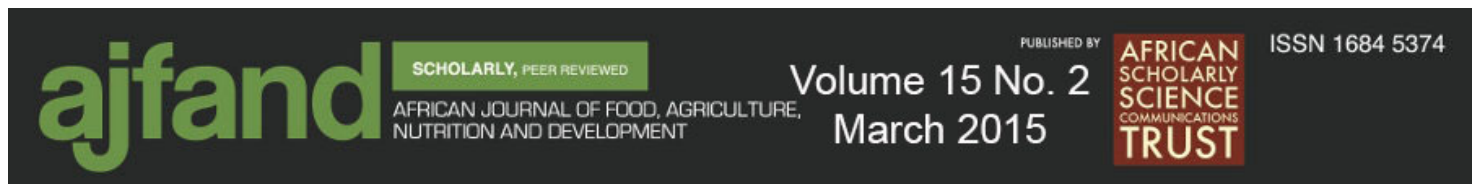

\begin{abstract}
Soil acidity affects seed yield and crop quality negatively due to aluminium toxicity in most humid tropics where the crop is cultivated for food and cash income by smallholder farmers. This study was conducted to assess the effect of different exchangeable aluminium concentrations on bean chemical quality of two common bean genotypes grown on lime-treated and lime-untreated soils. Factorial combinations of five aluminium rates $(0.0,12.5,25.0,50.0$, and $100.0 \mathrm{mg} \mathrm{Al} / \mathrm{kg}$ soil) and two common bean genotypes (New BILFA 58 and Roba 1) were laid out in a completely randomized design with three replications. For each treatment, four plants were raised per pot in the vegetation hall of Nekemte Soil Laboratory, western Ethiopia. The experiment was established in two sets: lime-treated soil and lime-untreated soil. The results revealed that aluminium toxicity caused major changes in the composition of the common beans. Significant differences $(\mathrm{P}<0.01)$ were found among the different aluminium rates and between the two genotypes for bean crude protein, crude fibre, crude fat, and ash, carbohydrate, calcium, magnesium, and aluminium contents under both liming regimes. The interaction of aluminium and genotype also influenced most of the bean chemical quality attributes negatively. New BILFA 58 (acidic soil tolerant genotype) had better bean chemical quality attributes (except aluminium and condensed tannins contents) than Roba 1 (acidic soil sensitive genotype) under both liming regimes. On the average, lime application increased bean crude protein, crude fat, ash, and calcium contents by $4.1 \%$, $20.7 \%$, 7.9\%, and $11.7 \%$, respectively. However, it decreased bean crude fibre and aluminium contents. Bean carbohydrate and condensed tannin contents of the genotypes increased in response to increasing aluminium application under both liming regimes. The total ash, which is an indirect indicator of the mineral content of foodstuffs, was found to be higher for New BILFA 58 than Roba 1 under both liming regimes. In conclusion, the results of this study have demonstrated that increased soil aluminium contents have significant negative effects on common bean quality, but integrated use of tolerant genotypes and application of lime can simultaneously alleviate the problem of low yield and reduced bean nutritional quality of the crop.
\end{abstract}

Key words: Aluminium, proximate, Lime, soil, Phaseolusvulgaris 


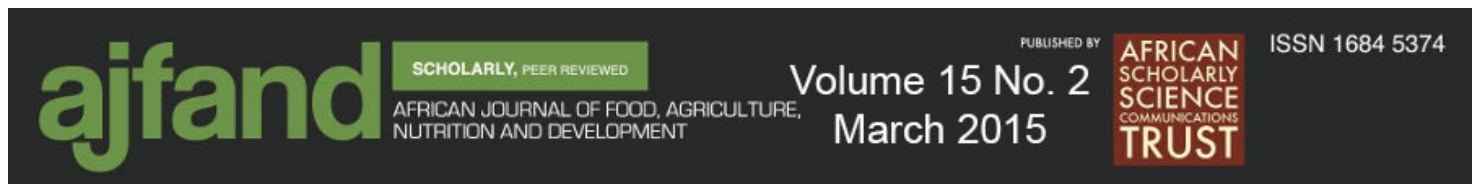

\section{INTRODUCTION}

Aluminium (Al) toxicity is a major agricultural problem in acid soils, and has been intensively studied in plants. Plants grown in acid soils due to $\mathrm{Al}$ solubility at low $\mathrm{pH}$ have undeveloped root system and exhibit a variety of nutrient-deficiency symptoms, with the consequence of decreased yields. Al interferes with the uptake, transport, and utilization of essential nutrients including $\mathrm{Ca}, \mathrm{Mg}, \mathrm{K}, \mathrm{P}, \mathrm{Cu}, \mathrm{Fe}, \mathrm{Mn}$ and $\mathrm{Zn}$ [1].

Common bean (Phaseolus vulgaris L.) is a food legume grown on more than four million hectares annually in Africa. It provides dietary protein for over 100 million people in rural and poor urban communities, with an annual per capita bean consumption of 50 to $60 \mathrm{~kg}$ in Eastern Africa being the highest in the world [2]. However, these benefits derived from the crop are challenged in many parts of the continent by multiple constraints that limit productivity [3]. Diets of subsistence farmers in Africa and South America often contain high carbohydrates (through cassava, maize, rice, wheat, (extra), but are poor in proteins [4]. Common bean provides proteins, essential amino acids, minerals such as $\mathrm{Fe}, \mathrm{Cu}, \mathrm{Zn}, \mathrm{P}, \mathrm{K}, \mathrm{Mg}$ and $\mathrm{Ca}$, starch and dietary fibre [4]. In nutritional terms, beans are often called the "poor man's meat" because they are a source of inexpensive protein and rich in minerals (especially iron and zinc) and B-vitamins [5]. However, in addition to the nutritional components, beans also contain some antinutritional factors such as protease inhibitors, tannins, and phytic acids [6].

Common beans are produced in South America and Africa mainly by smallholder farmers often on hillsides characterized by soils with low fertility, where nearly $40 \%$ of production areas are affected by soil acidity and aluminium (Al) toxicity, resulting in a 30 to $60 \%$ reduction in yield [4]. In addition to yield and other agronomic features, the evaluation of genetic materials for improved common bean seed quality is necessary in the production of the crop since a cultivar with poor bean quality may be rejected by processors and consumers regardless of agronomic superiority [7]. In addition, knowledge on the physicochemical properties of agro-materials is of importance to plant breeders, food scientists, grain processors, and consumers [8].

Al toxicity affects growth and gas exchange [9], carbohydrate content [10], mineral nutrition [11], organic acid metabolism [12], and nitrogen metabolism [13] of the shoots of plants. It also appears as an induced calcium deficiency or as reduced $\mathrm{Ca}^{2+}$ transport within plants, causing curling or rolling of young leaves, inhibited growth of lateral branches, or a collapse of growing points on branches [14]. Several studies have reported genotypic variability in plant growth, physiology, and quality in response to Al toxicity [15].

Information on bean chemical quality of common beans grown on different type of soils in Ethiopia is scanty. Therefore, knowledge on the nutrient contents and anti-nutritional factors of common bean genotypes that are grown in acidic soils is important for researchers, food processors, nutritionists, and farmers growing the crop. The objective of this experiment was to assess the effect of exchangeable aluminium concentrations on bean quality of two common bean genotypes grown on lime-treated and lime-untreated soils. 


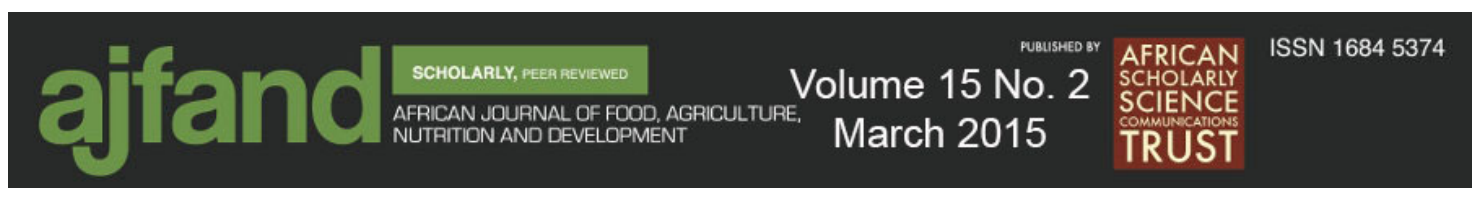

\section{MATERIALS AND METHODS}

\section{Description of the Study Area}

The experimental site is located at Nekemte, western Ethiopia at $9^{\circ} 08^{\prime} \mathrm{N}$ latitude and $36^{\circ} 46^{\prime}$ E longitude with an altitude of 2080 metres above sea level. According to the weather data recorded at the Nekemte Meteorological Station, the average annual rainfall of the study site is $1300 \mathrm{~mm}$ with $725 \mathrm{~mm}$ for the experimental period (July - October) and the monthly mean minimum and maximum temperatures are between 10 to $15^{\circ} \mathrm{C}$ and 24 to $28^{\circ} \mathrm{C}$ (Figure 1). The soil used for the pot experiment had a $\mathrm{pH}\left(\mathrm{H}_{2} \mathrm{O}\right)$ of 4.81 , exchangeable acidity of $4.92 \mathrm{cmol}(+) / \mathrm{kg}$ soil, exchangeable $\mathrm{Al}$ of $3.1 \mathrm{cmol}(+) / \mathrm{kg}$ soil, and acid saturation of $53.3 \%$ before applying the treatment.

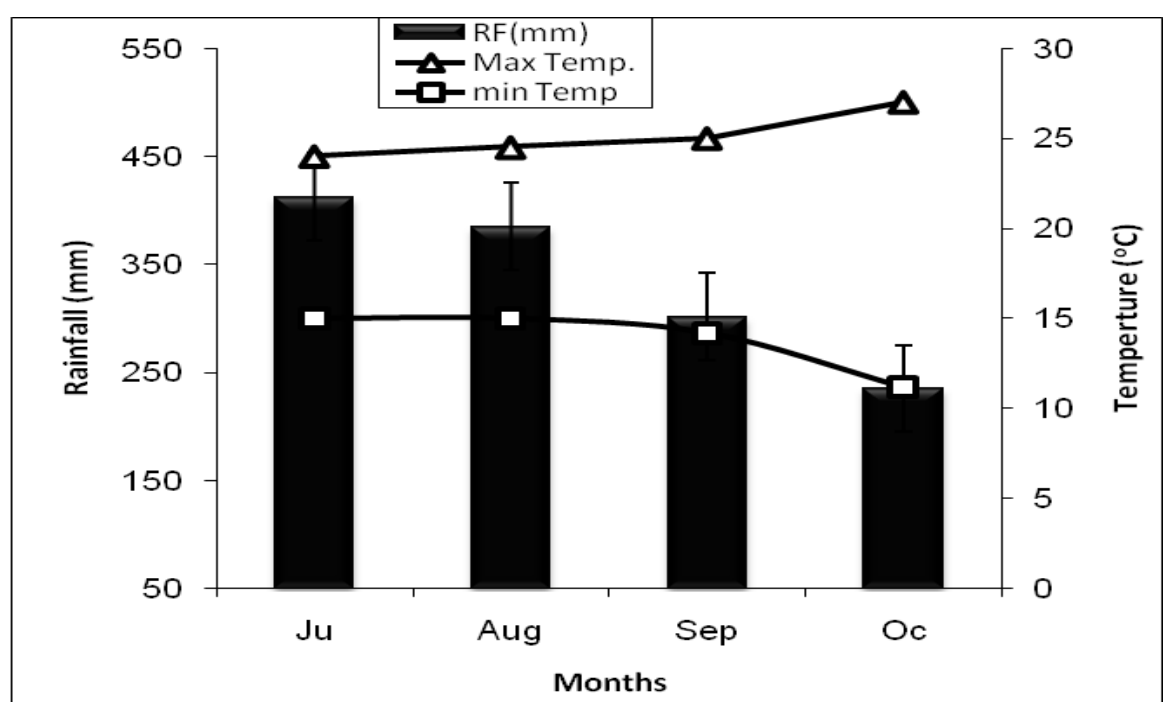

Figure 1: Rainfall distribution and mean minimum and maximum temperatures of the experiment site (Nekemte) during the experimental period (June to October), 2011

\section{Description of Planting Materials}

Results from previous field ( $\mathrm{pH} 4.5$ ) and pot ( $\mathrm{pH} 4.8$ ) screening experiments conducted in 2009 and 2010, respectively, revealed that new BILFA 58 (NB 58) and Roba1 were identified as the most tolerant and sensitive genotypes to soil acidity, respectively [16]. New BILFA 58 is a genotype with type III growth habit having large-sized seeds (53 g per 100 seed) whereas Roba 1 is a small-seeded ( 22 g per 100 seed) commercial cultivar in Ethiopia with the type II growth habit.

\section{Treatments and Experimental Design}

The treatments consisted of factorial combinations of the two common bean genotypes (new BILFA 58 and Roba 1) grown in pots under five rates of aluminium (0.0, 12.5, 25.0, 50.0, and $100.0 \mathrm{mg} \mathrm{Al} / \mathrm{kg}$ soil) applied to the soil in the form of $\mathrm{Al}_{2}\left(\mathrm{SO}_{4}\right)_{3}$. The experiment was laid out in a completely randomized design with three replications per treatment. The experiment consisted of two sets, one set with common bean plants grown on lime-treated soil and the other set on lime-untreated soil. 


\section{Experimental procedure}

Seeds of the two common bean genotypes were sown in pots $(18 \mathrm{x} 18 \mathrm{~cm})$ each filled with $10 \mathrm{~kg}$ soil. At the time of planting, the soil was fertilized with phosphorus at the rate

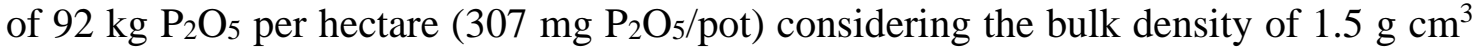
and a soil depth of $20 \mathrm{~cm}$. Initially, six seeds were sown per pot and later thinned to four plants when the first trifoliate leaves unfolded. The different rates of aluminium and lime were applied four weeks prior to planting the seeds and worked into the soil. Lime was applied at the rate of $20 \mathrm{~g} /$ pot ( 9 tonnes/hectare) after determining the amount by the incubation method [17]. Pots were watered periodically with tap water to the approximate field capacity to facilitate normal plants growth. Agronomic management practices including weeding were applied as required. The beans were harvested as maturity and dried to the moisture content of $12.5 \%$.

\section{Determination of proximate composition of the beans}

Moisture, total ash, crude protein, crude fat, and crude fibre contents of the beans were determined in the laboratory according to AOAC [18] using the official methods 925.09, 923.03, 979.09, 4.5.01 and 962.09, respectively.

\section{Moisture}

This was determined by drying a common bean flour sample weighing $5 \mathrm{~g}$ in an oven (Memmert 854 Schwabach, Germany) at $102^{\circ} \mathrm{C}$ for 5 hrs (AOAC method 925.09) [18]. Then, the moisture content was estimated by using the following formula:

$$
\text { Moisture }(\quad)=\left[\frac{\text { Massofinitialsample }- \text { Massofdrysample }}{\text { Massofinitialsample }}\right] * 100
$$

\section{Ash}

Ash content was determined after carbonizing a common bean flour sample weighing 2 and by igniting in a muffle furnace (GALLENKAMP, Model FSL 340-0100, U.K.) at $550^{\circ} \mathrm{C}$ until ashing was completed (over $12 \mathrm{~h}$ ) (AOAC method 923.03) [18]. Then, the ash content was estimated by the following formula:

$$
\operatorname{Totalash}(\quad)=\left(\frac{W 2-W}{W 1-W}\right) * 100
$$

Where, $W=$ mass in grams of empty dish

$W 1=$ Mass in grams of the dish plus sample dry matter basis ( $\mathrm{db})$

W2 = Mass in grams of the dish plus ash

\section{Crude protein}

Crude protein content was analysed from a common bean flour sample weighing $1 \mathrm{~g}$ using the micro-Kjeldahl (Automatic Steam distillation unit, UDK142, UK) method of nitrogen $(\mathrm{N})$ analysis (\% crude protein $=\% \mathrm{~N} * 6.25$ ) using urea as control (AOAC method 979.09) [18].

$$
\operatorname{TotalNitrogen}(g)=\frac{(V 2-V 1) * N * 14.007}{W}
$$


Where, V2 = Volume in $\mathrm{mL}$ of the standard sulphuric acid solution used in the titration for the test material; V1= Volume in $\mathrm{mL}$ of the standard sulphuric acid solution used in the titration for the blank determination; $\mathrm{N}=$ Normality of standard sulphuric acid; $\mathrm{W}=$ mass of sample (db) and 14.007 atomic mass of nitrogen.

4. Crude fat

Crude fat content was determined by the gravimetric method from a dried common bean flour sample weighing $5 \mathrm{~g}$ and extracting with ether using the Soxhlet extraction method for at least $4 \mathrm{~h}$ (AOAC method 4.5.01)[18]. The crude fat content was determined by the following formula:

$$
\text { Crudefat }(\quad)=\left(\frac{\mathrm{Wa}-\mathrm{Wb}}{\mathrm{WD}}\right) * 100
$$

Where, $W a=$ mass of extraction flask + fat extracted; $W b=$ mass of extraction flask; $W_{D}=$ mass of sample $(\mathrm{db})$.

\section{Crude fibre}

Crude fibre content was analysed by taking a common bean flour sample weighing $1.5 \mathrm{~g}$ as a portion of carbohydrate that resisted sequential digestion with $1.25 \%$ sulphuric acid and $1.25 \% \mathrm{KOH}$, followed by sieving through 75 microns, drying at $130^{\circ} \mathrm{C}$ for $2 \mathrm{hrs}$ in an oven (Memmert 854 Schwabach, Schwabach, Germany), ashing in a muffle furnace (GALLENKAMP, Model FSL 340-0100, London, U.K.) until ashing was completed (over $1 \mathrm{~h}$ ) and subtracting the ash from fibre (AOAC method 962.09) [18]. The crude fibre content was determined by using the following formula:

$$
\begin{aligned}
& (W 1-W 2) \\
& \text { * } 100 \\
& \text { Crudefiber ( ) = }
\end{aligned}
$$

Where, $W 1$ = crucible mass + sample after drying; W2= crucible mass + sample after ashing and $\mathrm{W} 3=$ initial sample mass $(\mathrm{db})$.

\section{Total carbohydrates}

Total carbohydrate was determined by difference as follows:

Totalcarbohydrate $(\quad)=100-($ moisture + protien + crudefiber + crudefat + ash $)$.

\section{Determination of bean mineral contents}

Calcium, magnesium, and aluminium contents of the beans were determined after dry digestion of the bean flour samples (about $1 \mathrm{~g}$ ) by atomic absorption spectrophotometer (Varian SpectraAA-20 Plus, Varian Australia Pty., Ltd., Australia) using air-acetylene gas as an energy source for the atomization (method 927.02, 920.09 and 928.03, respectively)[18]. For $\mathrm{Ca}$ and $\mathrm{Mg}$ analysis, $1 \%$ lanthanum solution (1mL La solution/5 $\mathrm{mL}$ or $20 \mathrm{~mL}$ per $100 \mathrm{~mL}$ flask) was added to the samples and standardised to suppress 


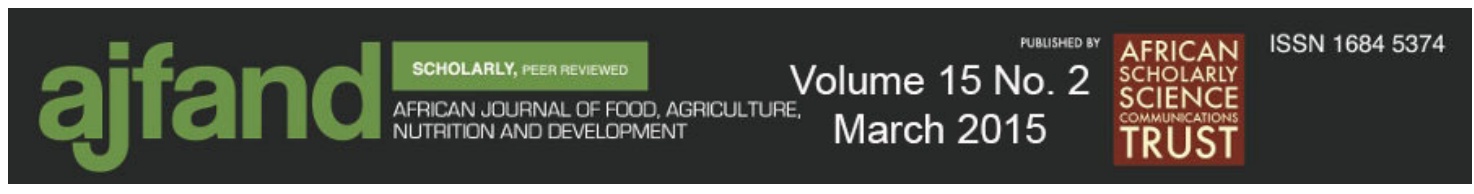

interference from phosphorus. For calcium analysis, absorbance was measured at 422.7 $\mathrm{nm}$ and the calcium content was estimated from the standard solution $(0.1-1.0 \mu \mathrm{g} \mathrm{Ca} / \mathrm{mL})$ prepared from $\mathrm{CaCO}_{3}$. For the determination of magnesium content, absorbance was measured at $285.2 \mathrm{~nm}$ and the content of the mineral was estimated from a standard calibration curve $(0.2-2.0 \mu \mathrm{g} 3000 \mathrm{x} \mathrm{g} / \mathrm{mL})$ prepared from an analytical grade $\mathrm{Mg}$ metal ribbon. For determination of aluminium content, emission was measured at $396.15 \mathrm{~nm}$ and the aluminium content was estimated from a standard calibration curve (0.2-20 $\mu \mathrm{g}$ $\mathrm{Al} / \mathrm{mL}$ ) prepared from an analytical grade $\mathrm{Al}$ metal. All determinations were done in duplicates.

$$
\text { Element }\left(\text { ppmor mg/1000 g) }=\frac{(\mu g / \mathrm{mL}) \times 100}{\text { Sampleweight }(g)}\right.
$$

Where: $\mu \mathrm{g} / \mathrm{mL}$ is concentration of analyte and 100 is original volume. Finally the result was expressed in $\mathrm{mg} / 100 \mathrm{~g}$.

\section{Condensed tannin}

Condensed tannin contents were analysed using the vanillin- $\mathrm{HCl}$ assay method of [19]. Sample (about $200 \mathrm{mg}$ ) was extracted with $100 \%$ methanol through vortex mixing for 20 minutes, centrifuging ( $3000 \mathrm{x} g$ for $10 \mathrm{~min}$ ), and using the supernatant in the analysis. Sample extracts $(1 \mathrm{~mL})$ was mixed with $5 \mathrm{~mL}$ of vanillin- $\mathrm{HCl}$ reagent in test tubes and was then incubated at $30^{\circ} \mathrm{C}$ in water bath for 20 minutes. A sample blank in which the vanillin reagent was replaced by $4 \% \mathrm{HCl}$ in methanol was included. Absorbance at 500 $\mathrm{nm}$ was measured using Spectrophotometer (UV/Vis Spectrophotometer, 6505, CM63LB, Jenway Ltd, Essex, UK) and blank absorbance was subtracted from the sample. Catechin was used as a standard and the result was expressed as catechin equivalents (CE)/g sample (db).

\section{Data Analysis}

Data were subjected to analysis of variance (ANOVA) according to the Generalized Linear Model of SAS version 9.01[20]. Mean differences were separated using the least significant difference (LSD) test at $5 \%$ level of significance.

\section{RESULTS}

\section{Effect of aluminium on proximate composition of beans}

Proximate composition of beans was significantly $(\mathrm{P}<0.05)$ influenced by the main and the interaction effects of aluminium and the common bean genotype. The interaction terms of aluminium rate by genotype was significant for crude fat and total ash contents of the common bean genotypes under both soil liming regimes, and for crude fibre under the lime-untreated soil. There was no significant difference in bean moisture contents of the genotypes for both lime-treated and lime-untreated soils. Genotypic differences were not observed also for crude fat content under lime-untreated soil. The moisture content of the flour ranged from 8.2 to $9.4 \%$ in lime-untreated soil and from 7.5 to $9.1 \%$ in limetreated soil with the average values of 8.9 and $8.3 \%$, respectively. 


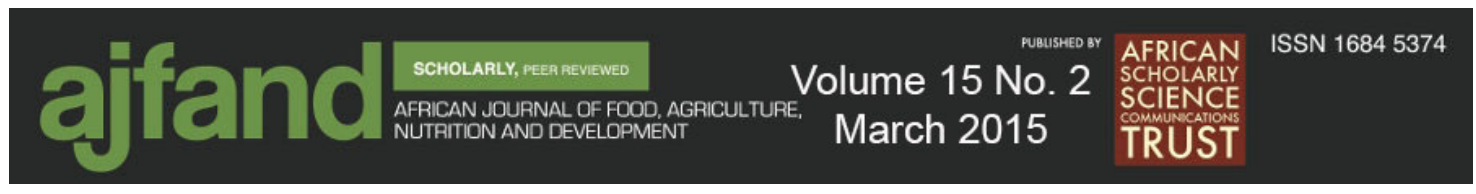

On average, the genotypes produced significantly higher crude protein, ash, and crude fat in the lime-treated soil than in the lime-untreated soil (Table 1, Figure 2). The bean crude protein content was markedly reduced in response to increasing the rate of aluminium application in both lime-treated and lime-untreated soils. However, the magnitude of reduction was higher in the lime-untreated soil (Table 1). The mean bean crude protein contents of the genotypes were $24.5 \%$ for the lime-untreated soil and $25.5 \%$ for the lime-treated soil. New BILFA 58 had higher crude protein content than Roba 1 at each aluminium level under both lime-treated and lime-untreated soils (Table 1). The bean crude protein content of BILFA 58 was reduced by $3.8 \%$ and that of Roba 1 was reduced by $4.21 \%$ when grown on the lime-untreated soil relative to the limetreated soil.

Crude fibre and fat contents of the beans were affected by aluminium levels and genotypes. The highest crude fibre content was recorded in response to applying aluminium to the lime-untreated soil at the highest rate. The first four aluminium rates resulted in similar values of crude fibre content. The acidic soil sensitive genotype (Roba 1) had higher crude fibre content than BILFA 58 under both liming regimes, with higher crude fibre contents recorded for the lime-untreated soil than the lime-treated soil. On average, lime application reduced the bean crude fibre content by $8.7 \%$. Application of lime to the soil reduced the crude fibre content of new BILFA 58 by $10.2 \%$ and that of Roba 1 by 7.8\% compared to no application of the material. Crude fat content of New BILFA was higher than that of Roba 1(Figure 2). Lime application improved bean fat content by ca. $20.7 \%$ on average (21.8\% for new BILFA 58 and $19.7 \%$ for Roba 1$)$.

The two genotypes varied in bean total carbohydrate content under both liming regimes. Higher values were recorded for Roba 1 than New BILFA 58 under both growth conditions (Table 1). Lime application increased the bean ash contents of the genotype by $7.9 \%$ over the untreated soil condition. New BILFA 58 had lower ash content than Roba 1 under both soil liming regime (Figure, 2). 

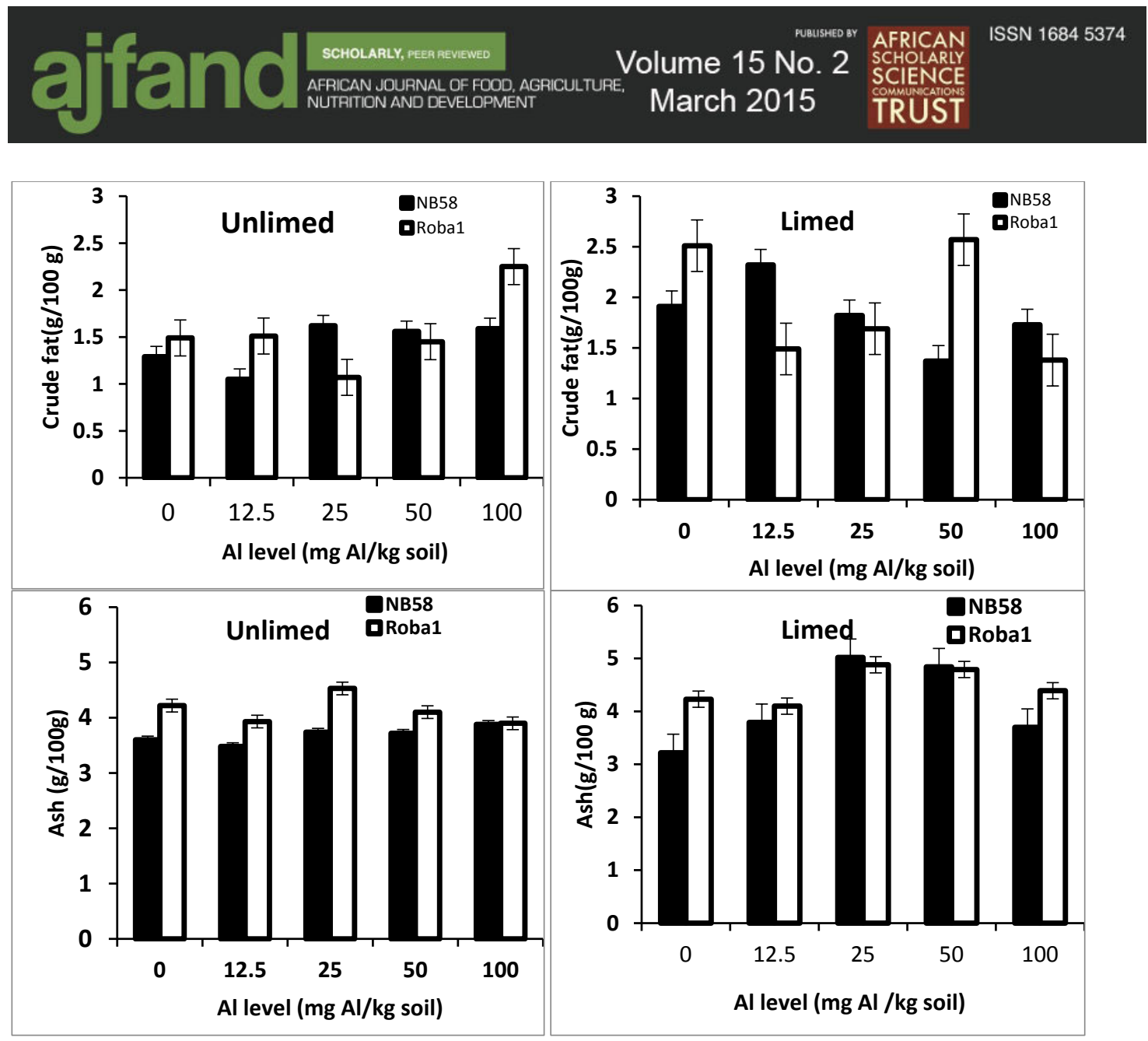

Figure 2: Crude fat $(\mathrm{g} / \mathbf{1 0 0 g})$ and ash $(\mathrm{g} / \mathbf{1 0 0 g})$ contents of two common bean genotypes (NB58- new BILFA 58 and Roba 1) grown under different levels of aluminium (Al) with lime-treated and lime-untreated soils

\section{Calcium and magnesium contents of beans}

The main as well as the interaction effects of genotype and aluminium rate significantly $(\mathrm{P}<0.01)$ influenced seed calcium and magnesium contents under both soil liming regimes (Figure 3). Higher $\mathrm{Ca}$ and $\mathrm{Mg}$ contents in the seed were recorded for new BILFA 58 than Roba 1 under both soil liming regimes. Evidently, the calcium content of the bean was improved by lime application. On average, lime application improved bean calcium contents by $11.7 \%$ (12.7\% for new BILFA 58 and for 10.4\% Roba 1). The highest calcium contents of the bean were recorded for the control (no aluminium) treatment but the lowest was recorded for the treatment with the maximum rate of aluminium application (100 mg Al/kg soil) under both liming regimes. Bean magnesium content, on the other hand, was unaffected by lime application. With the application of the different aluminium rates, New BILFA 58 attained higher bean Ca and Mg contents than Roba 1 (Figure 3). The contents of $\mathrm{Ca}$ and $\mathrm{Mg}$ in the bean decreased in response to the increased application of aluminium in both lime-untreated and lime-treated soils. However, the magnitude of the reduction was higher for the lime-untreated soil than the lime-treated soil (Figure 3). 


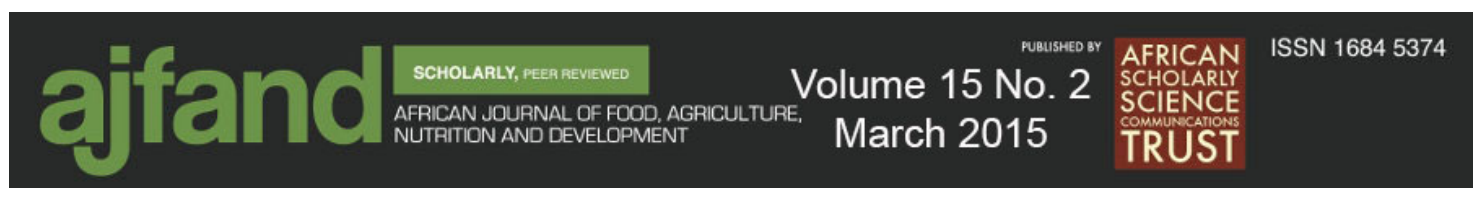

\section{Aluminium content of beans}

Significant differences in bean $\mathrm{Al}$ content was found between the two genotypes, liming regimes, and among the aluminium rates applied (Figure 3). As compared to the control treatment, application of aluminium at different rates significantly increased the bean aluminium content under both lime-treated and lime-untreated soil conditions. With the increase in the rate of aluminium application, the bean aluminium content also increased drastically. However, the increment was higher under the lime-untreated soil than under the lime-treated soil for the sensitive genotype (Roba 1). Generally, the seed aluminium content of the tolerant genotype (new BILFA 58 1) was lower than that of the sensitive genotype (Roba 1) when subjected to the different rates of aluminium. Bean aluminium contents of the genotypes decreased under the lime-treated soil as compared to the limeuntreated soil. On average, lime application reduced aluminium contents of the beans by 24.4\% (23.2\% for new BILFA 58 and 25.2\% for Roba 1). However, the magnitude of aluminium translocated and stored in the beans of both genotypes was small relative to the contents of the element found in the roots and shoots. 

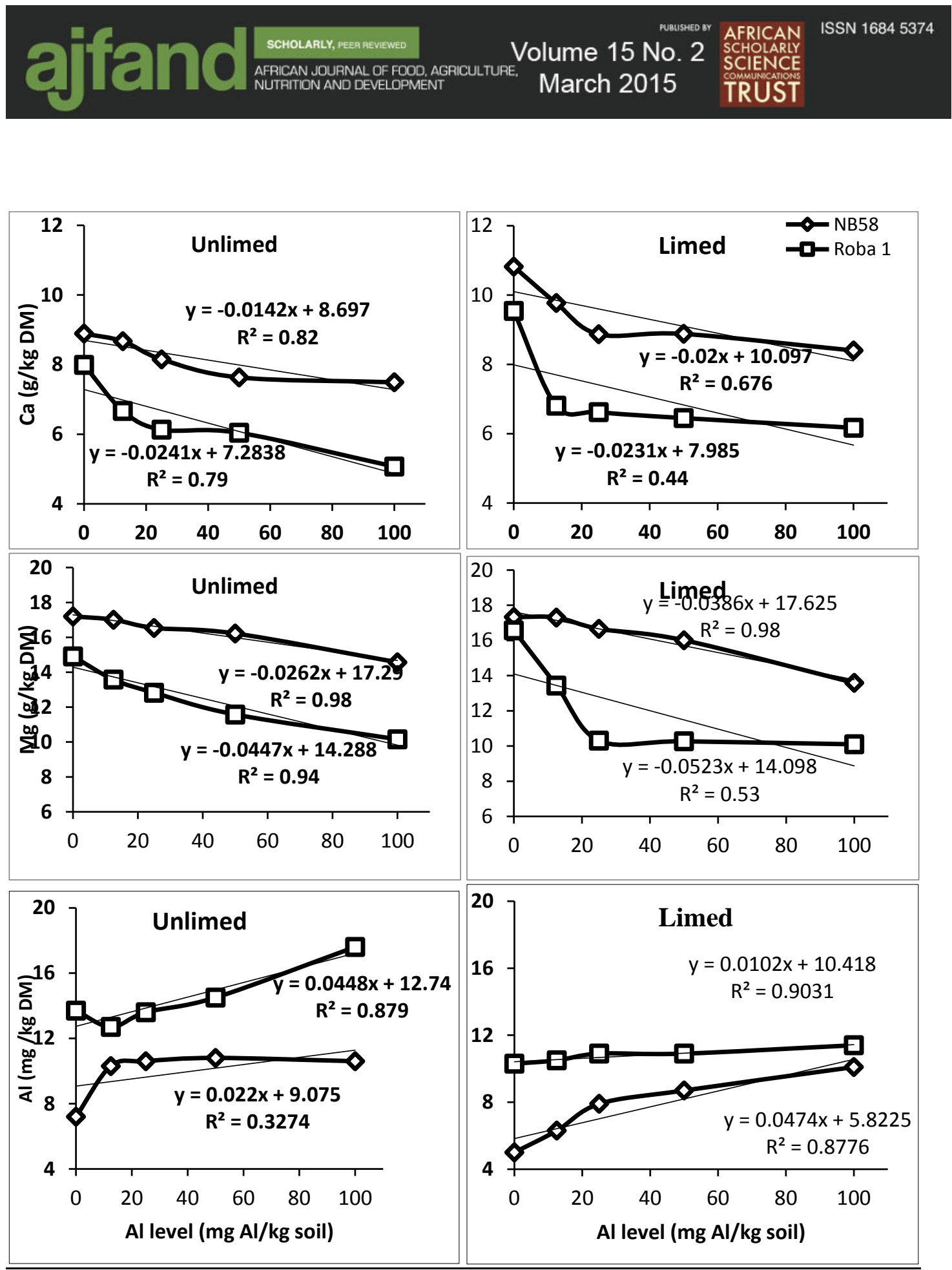

Figure 3: Calcium (g/kg db), magnesium (g/kg db) and aluminium (mg / $\mathrm{kg} \mathrm{db})$ contents of the two common bean genotypes grown under different levels of aluminium (Al) with lime-treated and lime-untreated soils

Condensed tannin contents of beans

Differences were found between the genotypes, soil liming regimes, and among the aluminium rates applied for condensed tannin contents of the common beans (Figure 4). Condensed tannin contents of the beans increased in response to increasing the rate of aluminium applied under lime-treated and lime-untreated soil conditions. However, the 


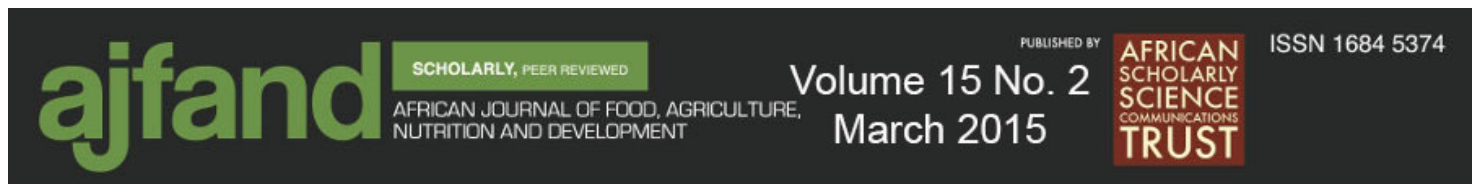

increment was significantly higher for Roba 1(Figure 4) than new BILFA 58 when the soil was not limed. Bean condensed tannin content started showing a marked increase at the second aluminium level (12.5 mg Al/kg soil) and continued increasing afterwards for both genotypes under both liming regimes (Figure 4). Bean tannin content of Roba 1 was consistently higher than that of new BILFA 58 at each aluminium level under both soil liming regimes. The difference in the bean tannin content of new BILFA 58 when grown under the two contrasting soil liming regimes was relatively small compared to the difference observed in Roba 1 under the same conditions.

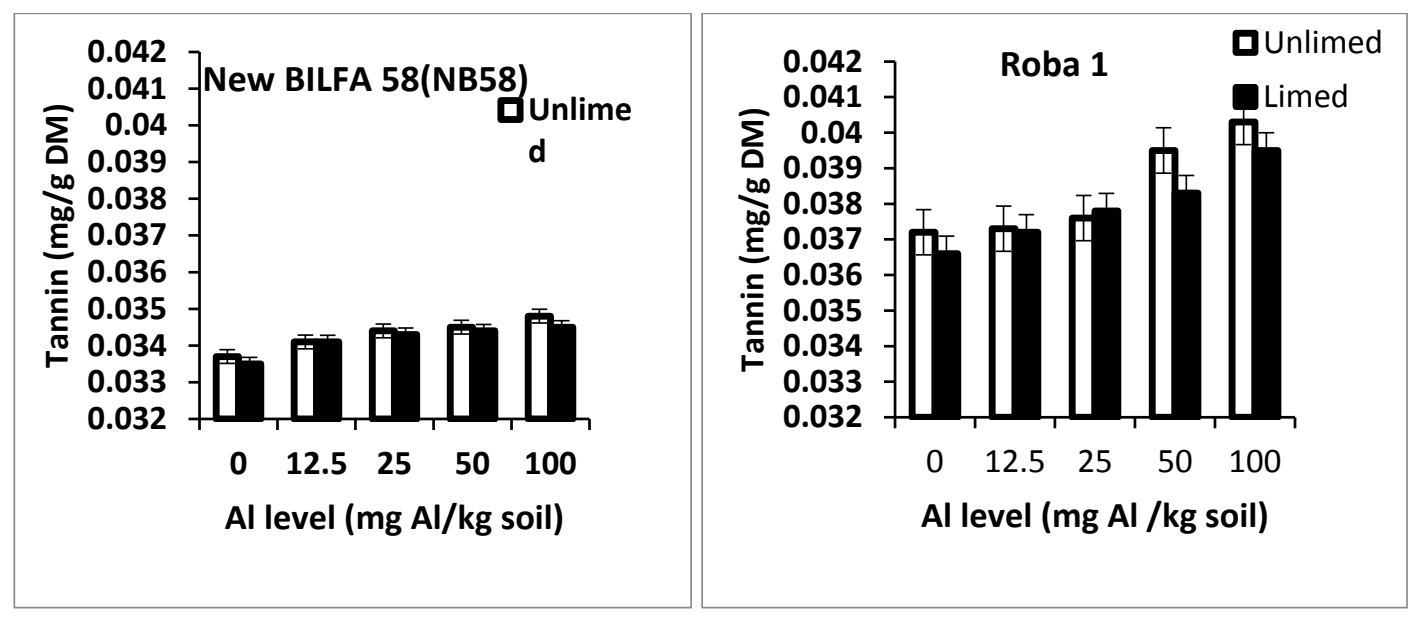

Figure 4: Bean condensed tannin contents (mg catechin equivalents /g db) of the two genotypes grown under different levels of aluminium (Al) on limetreated and lime-untreated soils

\section{DISCUSSION}

The effect of $\mathrm{Al}$ on plant growth and development was studied by different researchers and the results indicated that $\mathrm{Al}$ injury could affect different organs and plant parts in different ways [21]. The results of this study revealed that common bean proximate composition and elemental nutrient contents of the genotypes were differentially affected by the rate of aluminium applied to the soil. Aluminium toxicity caused major changes in the composition of the beans. The application of aluminium considerably reduced bean protein contents of both genotypes, the higher reduction being observed for the sensitive genotype (Roba 1). The results of this study concur with the findings of a similar study in which the content of sorghum leaf amino acid reduced significantly in response to aluminium application [22]. The reduction in the protein synthesis could be attributed to the role aluminium plays in promoting reduction in the adenosine tri-phosphate (ATP) levels, thereby restricting DNA transcription during protein synthesis [23]. In other words, aluminium has an indirect negative effect on protein synthesis due to reduction in ATP production that supplies energy to the process of protein synthesis [22]. The authors also reported that the reduction in protein content of aluminium-treated plants was linked to nitrate reductase activity, which becomes a limiting factor in the nitrogen assimilation under aluminium stress, consequently decreasing protein synthesis [22]. An inhibitory effect of aluminium on the soluble protein contents was reported also for pear millet [24]. 
Corroborating the results of this study, a stimulatory effect of aluminium stress on both reducing and non-reducing sugar levels was observed in the roots and shoots of wheat seedlings, with higher stimulatory effect on the aluminium tolerant cultivars [25]. The results of this study also demonstrated a stimulatory effect of aluminium on the total carbohydrate content of beans in response to the increased application of the element to the soil. The stimulatory effect of aluminium on bean total carbohydrate content was higher for the sensitive genotype (Roba 1) than the tolerant one (New BILFA 58).

The total ash, which is an indirect indicator of the mineral content of foodstuffs, was found to be higher for New BILFA 58 than Roba 1 under both liming regimes. In this study, aluminium application affected the uptake of calcium and magnesium and their translocation to the biological yield (beans) under both soil liming regimes. Furthermore, the genotypes exhibited differences in bean mineral composition under similar levels of aluminium treatment with or without application of lime to the soil. Generally, the acid soil tolerant new BILFA 58 was observed to have higher bean mineral composition than Roba 1. In line with this result, Mariano and Keltjens [28] reported that Al-tolerant maize genotypes had higher contents of $\mathrm{Ca}$ and $\mathrm{Mg}$ than sensitive genotypes. Similar results were reported by Foy [29] that aluminium toxicity affected calcium uptake and its contents in plants. According to Xiao et al. [30], aluminium interferes with the uptake, transport, and use of essential elements. It reduces the uptake and transport of calcium and magnesium in the plants [31]. Similar to this result, Jianweietal.[32] reported genotypic differences in the $\mathrm{Al}$ inhibition of long-distance $\mathrm{Ca}^{2+}$ transport when the root apical region was exposed to the element. In another study, the mechanism by which $\mathrm{Al}$ inhibits $\mathrm{Ca}^{2+}$ influx was reported to be due to blockage of $\mathrm{Ca}^{2+}$ channels by aluminium, which mediates $\mathrm{Ca}^{2+}$ transport at the plasma membrane [33].

The accumulation of aluminium in the beans was very small as compared to its accumulation in the roots and shoots of both common bean genotypes. This signifies that the applied lime apparently reduced uptake, translocation, and accumulation of the element in the beans of the two genotypes. Consistent with these results, Chen[34] reported that application of lime $\left(\mathrm{CaCO}_{3}\right)$ led to a significant decrease in aluminium contents in seeds. From the two genotypes, the uptake of aluminium by the sensitive genotype (Roba 1) was higher than that of the tolerant genotype (new BILFA 58). Similar to this result, Silva et al. [35], reported higher aluminium accumulation in the tissues of a sensitive wheat genotype than a tolerant one. However, in this study, bean aluminium contents of both genotypes were found to be below $0.02 \%$ under both lime-treated and lime-untreated soils. Thus, the translocation of aluminium to the beans was apparently very small compared to its accumulation in other parts of the plants. Consistent with these results, Liu et al.[36] reported that $\mathrm{Al}$ accumulation in the beans primarily and predominantly occurred in the root apoplast (30-90\% of the total absorbed Al) of peripheral cells, and is only very slowly translocated to more central tissues [37].

Leguminous species growing in the soil with large amounts of $\mathrm{Al}$ were found to have increased accumulation of tannins [38]. A similar result was observed in this study in which bean condensed tannin contents of both genotypes increased in response to the increased application of aluminium, with higher values occurring for the sensitive 
genotype (Roba 1) under no lime application. However, lime application decreased the bean condensed tannin content in both genotypes at the lower aluminium levels. In an earlier study, tannin content was reported to be 21.3 to $39.7 \mathrm{~g}$ catechinequiv $/ \mathrm{kg}$ seed in wild and cultivated beans under optimum growth conations [39]. In this study, relatively higher bean condensed tannin contents than the values often reported for common bean genotypes were observed. This may be partly attributable to aluminium toxicity which may have apparently led to increased condensed tannin contents of the common bean genotypes.

\section{CONCLUSION}

The results of this study showed that the chemical quality attributes (crude protein, ash, calcium and magnesium contents) of common beans were negatively affected by aluminium application to both lime-treated and lime-untreated soils. On the other hand, carbohydrate, crude fibre, aluminium and condensed tannin contents of the genotypes increased in response to the increasing rate of aluminium application. Treating the soil with lime improved the bean chemical and nutritive qualities of both genotypes. Integrating the cultivation of improved and acid soil tolerant common bean varieties with soil liming could alleviate the problems of low yield as well as poor nutritional quality of common bean in the study area, where production of the crop is markedly constrained by aluminium toxicity due to the high prevalence of soil acidity.

\section{ACKNOWLEDGEMENTS}

We are grateful to the Ministry of Education of Ethiopia for providing the fund required to do the research. Thanks are also due to Haramaya University for facilitating and technically supporting the research work. We thank all laboratory staff members of the Department of Food Science and Postharvest Technology of the University for the dedicated Technical Support they gave us in analysing bean quality parameters. 


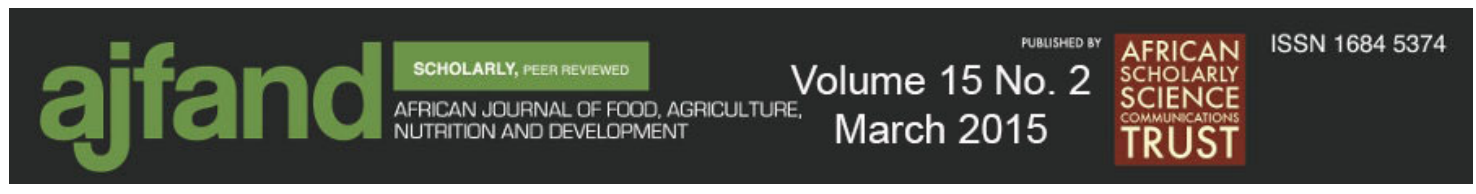

Table 1: Mean squares of bean chemical quality parameters of the two genotypes as affected by aluminium treatment and genotypes on unlimed and limed soils

\begin{tabular}{|c|c|c|c|c|c|c|c|}
\hline Parameters & Lime & $\mathrm{Al}$ & G & $A{ }^{*} G$ & Error & Mean & $\mathrm{CV}(\%)$ \\
\hline \multirow[t]{2}{*}{ Moisture (\%) } & UL & $1.25^{\star * \star}$ & $0.002^{\mathrm{ns}}$ & $0.398^{\mathrm{ns}}$ & 0.162 & 8.9 & 4.6 \\
\hline & L & $3.012^{* k *}$ & $0.009^{n s}$ & $0.139 \mathrm{~ns}$ & 0.048 & 8.3 & 2.7 \\
\hline \multirow[t]{2}{*}{ Crude protein (\%) } & UL & $15.43^{* * \star}$ & $50.23^{\star \star \star}$ & $0.764^{\mathrm{ns}}$ & 0.545 & 24.5 & 3.0 \\
\hline & L & $2.04^{*}$ & $50.0^{\star \star \star}$ & $1.002^{\mathrm{ns}}$ & 0.555 & 25.5 & 2.9 \\
\hline \multirow[t]{2}{*}{ Crude fibre (\%) } & UL & $0.329^{* k *}$ & $0.817^{\star k \star}$ & $0.328^{* * *}$ & 0.042 & 4.6 & 4.4 \\
\hline & $\mathrm{L}$ & $0.267^{\star \star}$ & $1.216^{\star \star \star}$ & $0.098^{\text {ns }}$ & 0.053 & 4.2 & 5.5 \\
\hline \multirow[t]{2}{*}{ Crude fat (\%) } & UL & $0.389^{* * \star}$ & $0.124^{*}$ & $0.343^{* * *}$ & 0.0167 & 1.5 & 8.7 \\
\hline & $\mathrm{L}$ & $0.352^{\star \star \star}$ & $0.069 \mathrm{~ns}$ & $0.965^{\star \star \star}$ & 0.0194 & 1.9 & 7.4 \\
\hline \multirow[t]{2}{*}{ Ash (\%) } & UL & $0.18^{\star \star \star}$ & $1.06^{\star \star \star}$ & $0.117^{\star *}$ & 0.012 & 3.9 & 2.8 \\
\hline & $\mathrm{L}$ & $1.184^{* \star \star}$ & $0.954^{\star \star \star}$ & $0.357^{* \star *}$ & 0.001 & 4.3 & 0.5 \\
\hline \multirow[t]{2}{*}{ Total $\mathrm{CH}_{2} \mathrm{O}(\%)$} & UL & $8.293^{* * *}$ & $22.59^{\star \star *}$ & $0.387^{\mathrm{ns}}$ & 0.65 & 55.6 & 1.4 \\
\hline & $\mathrm{L}$ & $5.24^{\star \star}$ & $23.27^{\star \star}$ & $1.45^{\text {ns }}$ & 0.70 & 55.9 & 1.5 \\
\hline \multirow[t]{2}{*}{$\mathrm{Ca}(\mathrm{mg} / 100 \mathrm{~g})$} & UL & $0.041^{* \star *}$ & $0.24^{* k \star}$ & $0.0049^{* * *}$ & 0.000004 & 0.7 & 0.3 \\
\hline & $\mathrm{L}$ & $0.79^{\star * \star}$ & $3.72^{* \star *}$ & $0.0056^{* * *}$ & 0.00013 & 0.8 & 1.4 \\
\hline \multirow[t]{2}{*}{$\mathrm{Mg}(\mathrm{mg} / 100 \mathrm{~g})$} & UL & $1.19^{* * *}$ & $10.3^{* k \star}$ & $0.13^{* k *}$ & 0.00039 & 1.5 & 1.3 \\
\hline & $\mathrm{L}$ & $2.42^{\star \star \star}$ & $12.27^{\star \star \star}$ & $0.73^{\star \star \star}$ & 0.00078 & 1.4 & 1.9 \\
\hline \multirow[t]{2}{*}{$\mathrm{Al}(\mathrm{mg} / 100 \mathrm{~g})$} & UL & $11.21^{\star \star \star}$ & $154.6^{\star \star \star}$ & $6.55^{\star \star}$ & 0.901 & 12.6 & 7.8 \\
\hline & $\mathrm{L}$ & $8.79^{\star \star \star}$ & $77.12^{\star \star \star}$ & $3.61^{\text {** }}$ & 0.743 & 9.2 & 9.4 \\
\hline
\end{tabular}

$\mathrm{CH}_{2} \mathrm{O}=$ Carbohydrate; $\mathrm{Al}=$ aluminium; $\mathrm{G}=$ genotype; $\mathrm{CV}(\%)=$ coefficient of variation; $U L$-unlimed $=L=$ Limed $; g=$ gram $=C a=$ calcium $; M g=$ Magnesium 


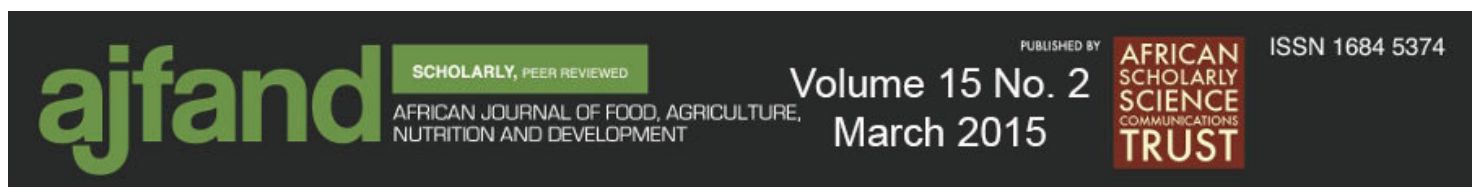

Table 2: Bean crude protein, moisture, crude fibre and carbohydrate contents of the two genotypes grown at different aluminium levels in lime-treated and lime-untreated soils

\begin{tabular}{|c|c|c|c|c|c|c|c|c|}
\hline \multirow{2}{*}{$\begin{array}{l}\text { Al } \\
\text { Level } \\
\text { (mg/kg } \\
\text { soil) }\end{array}$} & \multicolumn{2}{|c|}{ Crude protein (\%) } & \multicolumn{2}{|c|}{ Moisture (\%) } & \multicolumn{2}{|c|}{ Crude fibre (\%) } & \multicolumn{2}{|c|}{$\mathrm{CH}_{2} \mathrm{O}(\%)$} \\
\hline & UL & $\mathrm{L}$ & UL & $\mathrm{L}$ & UL & $\mathrm{L}$ & UL & $\mathrm{L}$ \\
\hline 0.0 & $26.8+0.5^{\mathrm{a}}$ & $26.4+0.5^{\mathrm{a}}$ & $8.7+0.3^{b}$ & $8.8+0.1^{\mathrm{a}}$ & $4.5^{+}+0.1^{\mathrm{b}}$ & $3.9+0.2^{\mathrm{c}}$ & $54.6^{\mathrm{b}}$ & $55.1^{\mathrm{b}}$ \\
\hline 12.5 & $25.4+0.7^{b}$ & $25.9+0.4^{\mathrm{ab}}$ & $8.2+0.1^{\mathrm{c}}$ & $7.5+0.04^{c}$ & $4.6+0.1^{b}$ & $4.2+0.1^{\mathrm{ab}}$ & $56.9^{\mathrm{a}}$ & $56.5^{\mathrm{a}}$ \\
\hline 25.0 & $24.3+0.9^{c}$ & $25.3+0.6^{\mathrm{bc}}$ & $9.1+0.2^{\mathrm{ab}}$ & $7.5+0.1^{c}$ & $4.5+0.2^{b}$ & $4.1+0.2^{\mathrm{bc}}$ & $56.6^{\mathrm{a}}$ & $56.3^{\mathrm{a}}$ \\
\hline 50.0 & $23.4+0.6^{\mathrm{d}}$ & $25.2+0.8^{\mathrm{bc}}$ & $9.4+0.01^{\mathrm{a}}$ & $9.1+0.01^{\mathrm{a}}$ & $4.6+0.01^{\mathrm{b}}$ & $4.3+0.1^{\mathrm{ab}}$ & $57.3^{\mathrm{a}}$ & $54.7^{\mathrm{b}}$ \\
\hline 100.0 & $22.8+0.7^{d}$ & $24.9+0.8^{c}$ & $8.9+0.2^{b}$ & $8.4+0.2^{\mathrm{b}}$ & $5.01+0.2^{\mathrm{a}}$ & $4.4+0.2^{\mathrm{a}}$ & $57.5^{\mathrm{a}}$ & $56.7^{\mathrm{a}}$ \\
\hline \multicolumn{9}{|c|}{ Genotypes } \\
\hline NB58 & $25.8+0.4^{\mathrm{a}}$ & $26.8+0.2^{\mathrm{a}}$ & $8.9+0.2^{\mathrm{ns}}$ & $8.3+0.2^{\mathrm{ns}}$ & $4.4+0.06^{\mathrm{b}}$ & $3.9+0.1^{\mathrm{b}}$ & $55.7^{\mathrm{b}}$ & $54.9^{\mathrm{b}}$ \\
\hline Roba 1 & $23.2+0.5^{b}$ & $24.3+0.3^{b}$ & $8.7+0.1^{\mathrm{ns}}$ & $8.2+0.2^{\mathrm{ns}}$ & $4.8+0.11^{\mathrm{a}}$ & $4.4+0.04^{\mathrm{a}}$ & $57.5^{\mathrm{a}}$ & $56.7^{\mathrm{a}}$ \\
\hline Mean & 24.51 & 25.53 & 8.86 & 8.25 & 4.59 & 4.19 & 55.6 & 55.9 \\
\hline CV (\%) & 3.01 & 2.9 & 8.3 & 2.7 & 4.44 & 5.5 & 1.42 & 1.5 \\
\hline
\end{tabular}

Where, UL- unlimed; $L$ - limed; $\mathrm{CH}_{2} \mathrm{O}=$ total carbohydrate; NB58-new BILFA 58, Means followed by the same letter in a column are not significant at $P \leq 0.05$ 


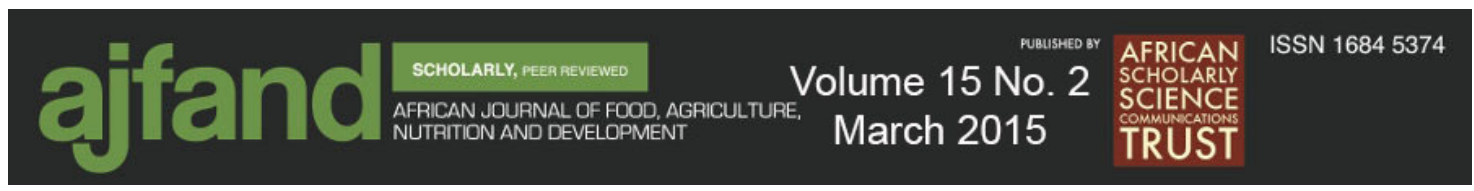

\section{REFERENCES}

1. Guo X, Flores M, Mavingui P, Fuentes SI, Hernández G, Dávila G and R Palacios Natural genomic design in Sinorhizobiummeliloti: novel genomic architectures. Genome Res.2003; 13: 1810-1817.

2. ISAR. Bean Program, Rwanda Agricultural Research Institute. http://www.isar.rw/spip.php. 2011, (last accessed 5 December, 2011).

3. Buruchara R, Chirwa R, Sperling L, Mukankusi C, Rubyogo JC, Muthoni R and MAbang Development and diversity of bean varieties in Africa: the Pan Africa bean Research Alliance (PABRA) model. African Crop Sci. J.2011; 19(4):227-245.

4. Broughton WJ, Hernadez G, Blair M, Beebe S, Gepts $\mathbf{P}$ and $\mathbf{J}$ Vanderleyden Bean (Phaseolus spp.)-Model food legumes. Plant Soil.2003; 252: 55-128.

5. Beebe S, Skroch PW, Tohme J, Duque MC, Pedraza F and J NienhuisStructure of genetic diversity among common bean landraces of Middle American origin based on correspondence analysis of RAPD. Crop Sci.2000; 40: 264-273.

6. Supradip S, Singh G, Mahajan V and HS Gupta Variability of Nutritional and Cooking Quality in Bean (Phaseolus vulgaris L) as a Function of Genotype. Plant Foods Human Nutrition.2009; 64:174-180.

7. Ghaderi A, Hosfield GL, Adams MW and MA UebersaxVariability in culinary quality, component interrelationships, and breeding implications in navy pinto beans. Journal of the American Society and Horticultural Science.1984; 109, p: 85-90.

8. Ozturk I, Kara M, Elkoca E and S ErcisliPhysico-chemical grain properties of new common bean cv. 'Elkoca-05'.Scientific Research and Essay 4(2):088093(2009).

9. Pereira WE, de Siqueira DL, Martinez CA and M Puiatti Gas exchange and chlorophyll fluorescence in four citrus rootstocks under aluminum stress. J Plant Physiol.2000; 157:513-520.

10. Graham CJ Non-structural carbohydrate and prunasin composition of peach seedlings fertilized with different nitrogen source and aluminum. SciHortic. 2002; 94:21-32.

11. George E, Horst WJ and E Neumann Adaptation of plants to adverse chemical soil conditions. In: Marschner P (ed) Marschner's mineral nutrition of higher plants, 3rd edn. Elsevier, Amsterdam, 2012; pp. 409-472.

12. Watanabe $\mathbf{T}$ and $\mathbf{M}$ Osaki Role of organic acids in aluminum accumulation and plant growth in Melastomamalabathricum. Tree Physiol. 2002; 22:785-792. 


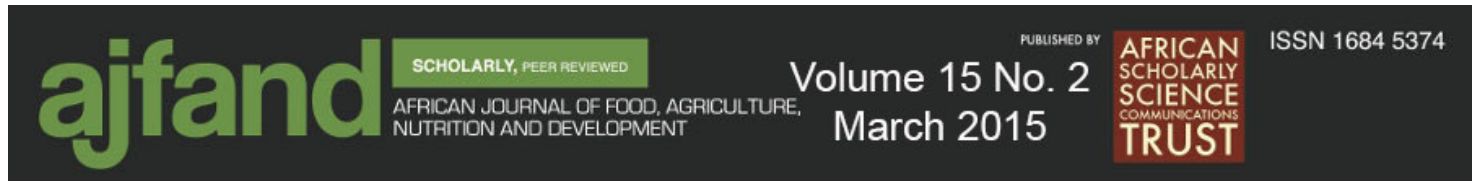

13. Xiao XX The physiological and biochemical response of longan (Dimocarpuslongan Lour.) to aluminum stress and rectification of aluminum toxicity. Fujian Journal of Agricultural Science, 2002;17:182-185.

14. Wang J. Raman H, Zhang G, Mendham $\mathbf{N}$ and $\mathbf{M}$ ZouAluminum tolerance in barely (Horidiumvulgarie L.): Physiological mechanisms, genetic and screening methods. Journal of Zhejiang University Science, 2006;7:769-787.

15. Liu S, Li Y and Tang Host resistance to an insecticide and selection at larval stage favour development of resistance in the parasitoid, Cotesiaplutellae”. In The management of diamondback moth and other crucifer pests. Proceedings of the Fourth International Workshop, 26-29 November 2001, Edited by: Endersby, NM and Ridland, 2004; PM. 227-233. Melbourne. Melbourne, Australia: Department of Natural Resources and Environment.

16. Hirpa L, Nigussie D, Setegn G, Geremew B and M FirewResponse to Soil Acidity of Common Bean Genotypes (Phaseolus vulgaris L.) Under Field Conditions at Nedjo, Western Ethiopia. Science, Technology and Arts Research Journal2013; 2(3): 03-15.

17. Dechassa $\mathbf{N}$ Phosphorus Efficiency of Selected Vegetable Crops. PhD Dissertation. Verlag-Grauer. Beuren Stuttgart. 2001;pp.166.

18. AOAC. Association of Official Analytical Chemists. Official Methods of Analysis (Vol. II 17th edition) of AOAC International. Washington, DC, USA. Official Methods 920.09, 920.39, 920.87, 923.03, 925.10, 927.02, 928.03 and 962.03(2000).

19. Price ML, Scoyoc SV and LGButtler critical evaluation of the vanillin reaction as an assay for tannin in sorghum. Journal of Agriculture and Food Chemistry,1978; 26 (5):1214-1218.

20. SAS. Institute Inc. SAS/STAT User's Guide: Version 9.1 ${ }^{\text {th }}$. SAS Institute Inc.,2004; Cary, North Carolina

21. Malmir HA, Mostajeran A, Almodares A, Asghari G, Afkhami A, Nassiryand $\mathbf{H}$ Hachellu The Effects of Aluminium on Fibre and Protein Bound Condensed Tannin, Polyphenols and Some Growth Index in Two Sorghum Cultivars. International Journal of Botany.2009; 5: 58-66.

22. Rodrigues da Cruz FJ, Lobato da Silva AK, Lobo da Costa RC, dos Santos Lopes MJ, Neves HKB, de Oliveira Neto CF, Lima da Silva MH, dos Santos BG Filho, and JA de Lima JuniorAluminum negative impact on nitrate reductase activity, nitrogen compounds and morphological parameters in sorghum plants. Australian Journal of Crop Science,2011; 5:641-645.

23. Lorenc-Plucinska $\mathbf{G}$ and $\mathbf{H}$ Ziegler Changes in ATP levels in scots pine needles during aluminium stress. Photosynthetic.1996;32: 141-144.

24. Albassam BA Growth and nitrate assimilation in pear millet exposed to aluminum stress. Saudi Journal of Biological Science.2001; 8(2):105-112. 
25. Scott R, Hoddinot J, Taylor GJ and JA kittrickThe influence of aluminum on growth, carbohydrate and organic acid content of an aluminum sensitive cultivar of wheat. Canadian Journal of Botany, 1991; 69:711-716.

26. Sathe SK and M Venkatachalam Beans In:C. Wrigley, II.Corker and C.E. Walker(eds) Encyclopaedia of grain science. Vol.1.Elsevier Academic Press Oxford, UK, 2004, PP.76-86.

27. Chen LS, Qi YP and XH LiuAluminum induced decreases in $\mathrm{CO}_{2}$ assimilation in citrus seedlings is accompanied by decreased activities of key enzymes involved in $\mathrm{CO}_{2}$ assimilation. Tree physiology, 2005b; 25:317-324.

28. Mariano ED and WG Keltjens Long-term effects of aluminum exposure on nutrient uptake by maize genotypes differing in aluminum resistance. Journal of Plant Nutrition, 2005; 28 (2): 323-333.

29. Foy CD Plant adaptation to acid, aluminum toxic soils, Commendams of Soil Science. Plant Analysis, 1988; 19:959-987.

30. Xiao XX, Chen LS, Cai YH, Huang Y and YQ Xie The effect of aluminum stress on the absorption of nutrient element in longan seedling. Acta Agriculture University of Jiangxiensis, 2005;27:230-233.

31. Berger TW, Eagar C, Likens GE and G Stingeder Effect of calcium and aluminum chloride additions on foliar and through fall chemistry in sugar maples. Forest Ecology and Management, 2001; 149: 75-90.

32. Jianwei WH, DavidC and LV KochianAluminum Effects on Calcium translocation in Aluminum-Tolerant and Aluminum-Sensitive Wheat (Triticumaestivum)Cultivars' Differential Responses ofthe Root Apex versus Mature Root Regions. Plant Physiolology, 1993;102:85-93.

33. Huang JW, Shaff JE, Grunes DL and LV KochianAluminum Effects on Calcium Fluxes at the Root Apex of Aluminum-Tolerant and Aluminum-Sensitive Wheat Cultivars. Plant Physiology, 1992; 98:230-237.

34. Chen Li Song Physiological Responses and Tolerance of Plant shoot to aluminum Toxicity. Journal of Plant Physiology and Molecular Biology, 2006;32(2):143155.

35. Silva SO, Pinto-Carnide P, Martins-Lopes M, Matos H, Guedes-Pinto and C Santos Differential aluminium changes on nutrient accumulation and root differentiation in an $\mathrm{Al}$ sensitive vs. tolerant wheat. Environmental and Experimental Botany, 2010; 68 (1):91-98.

36. Liu Q, Yang JL, He LS, Li YY and SJ Zheng Effect of aluminum on cell wall, plasma membrane, antioxidants and root elongation in triticale. BiologiaPlantarum, 2008; 52 (1):87-92.

37. Schmohl $\mathbf{N}$ and WJ Horst Cell wall pectin content modulates aluminum sensitivity of Zea mays (L.) cells grown in suspension culture. Plant Cell and Environment, 2000; 23 (7):735-742. 


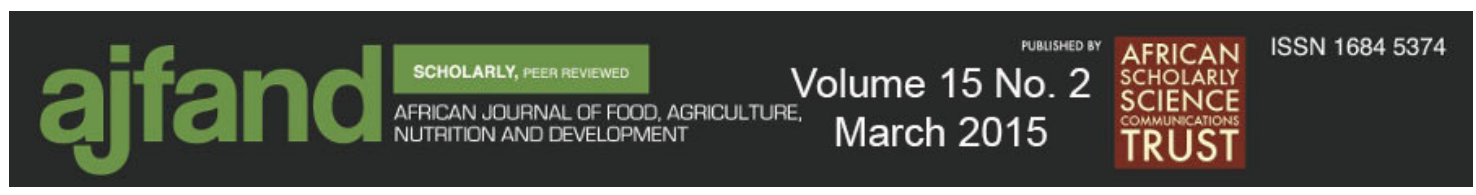

38. Kochian LV, Pineros MA and OA Hoekenga The physiology, genetics and molecular biology of plant aluminum resistance and toxicity. Plant and Soil, 2005; 274:175-195.

39. Guzman-Maldonado SH, Acosta-Gallegos $\mathbf{J}$ and $\mathbf{O}$ Paredes-Lopez Protein and mineral content of a novel collection of wild and weedy common bean (Phaseolus vulgaris L). Journal of the Science of Food and Agriculture, 2000; 80:1874-1881. 